\title{
ВПЛИВ ЗАКОНОДАВСТВА ЄВРОПЕЙСЬКОГО СОЮЗУ \\ В ДЕРЖАВАХ-ЧЛЕНАХ НА РЕГУЛЮВАННЯ СИСТЕМИ ОХОРОНИ ЗДОРОВ'Я ЩОДО ВИЗНАННЯ ПРАВА НА ЖИТТЯ ВІД МОМЕНТУ ЗАПЛІДНЕННЯ В КОНТЕКСТІ ВИМОГ БІОЕТИКИ
}

\section{Терешкевич Г. Т. (сестра Діогена)}

\section{ВСТУП}

Функціонування органів публічної влади всіх ієрархічних рівнів $\mathrm{i}$ прийняті ними управлінські рішення повинні спрямовуватися на захист фундаментальних людських цінностей (зокрема, базисного права людини на життя). Ці фундаментальні цінності особи має бути захищено не лише морально, але й юридично: йдеться про людські цінності, 3 приводу яких міжнародні трибунали $\mathrm{i}$ національні конституції повинні зайняти чітку позицію. Тут виникає проблема між етикою і правом, між моральним і цивільним законом.

Розумом до кінця неможливо пізнати всю велич Божественного Задуму трансцендентального шляху, що зветься життя. Тому залишається 3 трепетом і благоговінням прийняти цей дар, дякувати i берегти як неповторну цінність.

У момент злиття батьківських гамет відбувається диво сотворення людини, з тільки їй властивим набором генів та, відповідно, особистісних якостей, з неповторними характеристиками та талантами. 3a 38-40 тижнів внутрішньоутробного розвитку ця людська істота стане здатною до існування поза межами материнського лона й отримає ім'я. Але, на жаль, така доля чекає далеко не всіх зачатих людських істот через поширену у світі практику абортів, контрацепцію, штучне запліднення та інші сумнівні «здобутки» сучасної медицини за нехтування правами маленької людської істоти й пропагування в суспільстві «культури смерті», що є замахом на божественну гідність людської особи.

Необхідно звернути увагу на те, що 22 червня 1996 року Національний комітет Італії з питань біоетики прийняв документ «Ідентичність та статус людського ембріона», згідно з яким людський ембріон визнано таким, який заслуговує пошани й опіки, що застосовуються до людських індивідів, яким присвоєні характеристики особистості. У цьому документі записано: «Комітет одноголосно дійшов згоди щодо визнання моральним обов'язком трактувати людський ембріон від моменту запліднення (зачаття) відповідно до критеріїв пошани й опіки, які застосовуються до 
людських індивідів, яким присвоюється характеристика особистості» ${ }^{1}$ У цьому тексті вражає одностайність прийняття рішення 3 огляду на плюралістичний склад Комітету та всупереч полеміці, яка часто супроводжує обговорення питань щодо онтологічного та юридичного статусу людського ембріона. Таке рішення, поза сумнівом, стверджує позицію Комітету з двох важливих і дискусійних питань: визнання початком людського існування момент запліднення та застосування концепції особистості стосовно ембріона. Можливо, така одностайність пояснюється досягненням компромісу 3 двох пунктів: 1) ідеться не про юридичний, а про моральний обов'язок шанувати й опікувати ембріон; 2) ембріон треба трактувати згідно 3 тими самими критеріями, що застосовуються до «людських індивідів», яким присвоюється характеристика особистості. Специфічна особливість права полягає у регулюванні людських взаємин. Отож, Національний комітет Італії 3 питань біоетики визнає ембріон особою.

Постає питання: якою мірою конституційне право, зокрема, в сучасних інтерпретаціях суддів, тобто на вершині сучасної юридичної культури, де сама ідея правосуддя перетинається із суспільним порядком, трактує людський ембріон як особистість? Цілком зрозуміло, що це питання має конституційну природу, бо стосується самого існування, а радше розширення способу та діапазону дії опіки над правом на життя. Ця тема, що $є$ одним із найважливіших розділів біоетики та біоправа, бо тісно пов'язаний із питанням статусу ембріона, особливо важлива в сучасних умовах принаймні з п'яти причин.

По-перше, вона пов'язана 3 намаганнями - дуже типовими для нашого часу - програмувати та контролювати народження й початок людського життя. По-друге, досягнення наукового та технічного прогресу відкрили таємницю, яка раніше оточувала процеси внутрішньоматкового розвитку плоду, та прямують далі на щораз детальніше та глибше вивчення цих процесів; безперечним є факт, що навіть уже набуті знання є більш ніж достатніми, щоб звільнити цю галузь від грубих помилок, припущень, здогадів та уявлень. По-третє, міркування над питанням людських прав, - яке досягнуло переломного пункту після Другої світової війни з прийняттям Загальної декларації прав людини (10 грудня 1948 р.) - охоплює також питання володіння правами, отже безпосередньо стосується питання гідності та прав зачатої та ще ненародженої дитини ${ }^{2}$. По-четверте, необхідно проаналізувати

${ }^{1}$ Comitato Nazionale per la Bioetica. Identitá e statuto dell'embrione umano / Pressidenta del Consiglio dei Ministri. Dipartimento per l'Informazione e l'Editora. Roma, 22 giugno 1996. p. 25 .

2 Загальна декларація прав людини: прийнята і проголошена резолюцією 217 А (III) Генеральної Асамблеї ООН від 10 грудня 1948 р. / База даних «Законодавство України». URL: http://zakon.rada.gov.ua/laws/show/995_015. 
«авторитетне» твердження про існування тенденцій, спрямованих на «перетворення злочину на закон» (одягання в мантію законності (юридично та соціально) агресії проти людського життя, що приходить на світ), які призведуть до перелому, що матиме трагічні наслідки для історичного процесу; тобто після визнання прав людини як таких, що вважаються невіддільними, коли привселюдно стверджується цінність життя, а саме право на життя грубо зневажається та нехтується, зокрема, у найбільш символічних проявах людського існування - народженні та смерті ${ }^{3}$. По-п'яте, проблема права на життя ненародженої дитини прямо пов'язана 3 найбільшими проблемами сучасної юридичної культури. 3 вище окресленою проблемою прав людини перетинаються такі теми, як рівноправність, людська гідність, справедливість, демократія, мир, солідарність, свобода, становище жінки в суспільстві, сім'я, світський характер громадських, політичних і культурних сфер життя.

Необхідність і своєчасність постановки питання про природу та права зачатої та ще ненародженої дитини виникла спершу у зв'язку 3 феноменом узаконеного аборту, а згодом у зв'язку із застосуванням до людини технологій штучного запліднення. Перший феномен, незважаючи на те, що нині він поширений у світі (у Європі лише в Ірландії, на Мальті та в Сан-Маріно аборти заборонені законом), далекий від того, щоб бути закріпленим законодавчо. Навіть там, де узаконення штучного аборту відбулось найраніше, часто можна зауважити сигнали, які свідчать про переосмислення цього питання як на юридичному, так і на культурному рівнях ${ }^{4}$.

\section{1. Проблеми узгодженості норм права із засадами біоетики}

У процесі трансформації суспільства на засадах гуманізму та демократії особливого значення набувають проблеми цінності та гідності людського життя. Підвищення ефективності публічного управління потребує впровадження комплексних, системних і водночас гуманістично-ціннісних підходів, спрямованих на забезпечення прав людини на всіх етапах ії життя.

Як відомо, у сучасному світі система прав людини є розгалуженою. Гідність, притаманна людському індивіду на всіх етапах його існування, передбачає дотримання таких прав людини: права на життя; фізичних прав (інструментальних, соціальних, особистих); політичних прав (права на юридичний захист, права на самовизначення); права на пересування (права на внутрішню та зовнішню міграцію, права на

${ }^{3}$ Giovanni Paolo II. Lettera Enciclica Evangelium Vitae, 25 marzo 1995. Città del Vaticano : Libreria Editrice Vaticana, 1995. P. 31.

4 Терешкевич Г.Т. Основи біоетики та біобезпеки : підручник. Тернопіль : ТДМУ, 2018. С. 96. 
громадянство); права на об'єднання (права на соціальні взаємозв'язки); економічних прав (права на працю; права на власність); сімейних і сексуальних прав (права обирати сімейний стан; права на економічні, соціальні, культурні й моральні умови); релігійних прав (права на релігійну свободу; права на приватне й публічне сповідування своїх релігійних переконань); комунікативних прав (права на спілкування; права бути поінформованим правдиво; права на свободу самовираження, освіту й культурне життя).

$€$ й інші підходи щодо класифікації прав і свобод людини в сучасному суспільстві. Проте доцільно виділити головне, що саме право на життя людини є іï фундаментальним, базисним правом. Як слушно зауважує український науковець К. Карпенко, «...будь-які 3 колись проголошених прав людини можна розглядати як розгортання або конкретизацію цього основного права, тому що кожне 3 них обов'язково $є$ одним із проявів життя, задоволенням певних життєвих потреб, інтересів, прагнень» 5 .

Одвічна філософська дискусія про відносини між цивільним законом і законом моральним сьогодні $€$ важливим викликом для демократичного суспільства.

Ще св. Тома Аквінський наголошував на тому, що аж ніяк не вся сфера моралі може бути оповита правом. Закон, втім, не може обгрунтовувати мораль, у ліпшому разі він може визнати іiі вимоги. Тому не слід прагнути етичної держави, яка б вирішувала, що $є$ добро і що - зло. Однак фундаментальні цінності, необхідні для гарантування загального блага, має бути захищено також законом. I тому, якщо закон не захищає благо, необхідне для спільного проживання людей i загального добробуту (як, скажімо, закони, що допускають аборт), цей закон не $є$ законом, а отже, можливою $є$ відмова від його виконання за велінням совісті, і закон потрібно змінити.

Фундаментальне право на життя поодинокого живого створіння, яке вже народилось чи має з'явитися на світ, сім'я, необхідна медична допомога $€$ основними етичними реквізитами, тому що служать захисту загального блага. Це не якийсь «етичний мінімум», бо йдеться аж ніяк не про малі речі, а про загальне благо, яке потрібно захищати в інтересах усіх.

У сучасному плюралістичному суспільстві з огляду на цілу низку причин, а особливо внаслідок виникнення біоетичного мислення $\mathrm{i}$ поставлених ним проблем, що торкаються сфери закону, чимраз очевиднішою стає необхідність прояснення аксіологічних основ права для того, щоб зробити більш визначеними та явними невіддільні права

${ }^{5}$ Соціально-філософські та етичні проблеми медицини : навч. посіб. / за заг. ред. А.П. Алексєєнко, В.М. Лісового. Харків : Колегіум, 2010. С. 66-67. 
людини, які санкціоновано законом, повинні спрямувати поведінку людини у випадку морального вибору, до якого залучено науки про життя і здоров'я.

Нова наука біоетика виникла як реакція на нівелювання цінності людського життя внаслідок поглиблення загрози екологічної катастрофи, надмірного впливу нових технологій біології та медицини, обмеженого підходу до хворого, кризи патерналістських стосунків «лікар - пацієнт».

У панівній культурі розщеплення бінома «істина - свобода», як це не парадоксально, чимраз утруднює ефективний захист людського життя державними структурами та сприяє появі витончених форм тиранії, за яких купка людей може вирішувати долю багатьох інших.

Минуло вже не так мало часу відтоді, як закони про штучний аборт, чинні в багатьох західних країнах, по суті, перетворили поняття «злочин» у «право», яке узаконює зловживання владою сильніших стосовно життя слабших і невинних 6 .

Ця заплутана юридична ситуація, за якої цінність людського життя піднімається й опускається по шкалі цінностей, наче якийсь суб'єктивний інтерес, є наслідком етичного релятивізму та юридичного позитивізму, що перетворили теорію розрізнення права і моралі на теорію радикального поділу цих двох понять ${ }^{7}$.

У сучасних юридичних дискусіях часто можна почути про аморальність права. Урешті-решт, така думка призводить до концепції права, яка відтинає від себе будь-який критерій справедливості та загального блага ${ }^{8}$.

Дедалі більше авторів пропонують теорії етичного мінімуму, що залишають простір для моралі, але лише в тих межах, у яких мораль визнає абсолютний примат права i які спираються на моделі юридичних принципів, визнаних $\mathrm{i}$ санкціонованих міжнародними деклараціями прав людини. Там, де цього немає, мораль обмежується уявою окремих індивідів, без будь-якого юридичного «забезпечення» на колективному рівні ${ }^{9}$.

Згідно з цією доктриною, право має залежати не від істини, а радше від акту нормативної волі того, хто при владі (юридичний позитивізм) ${ }^{10}$.

${ }^{6}$ Giovanni Paolo II. Lettera Enciclica Evangelium Vitae, 25 marzo 1995. Città del Vaticano : Libreria Editrice Vaticana, 1995. N 11.

${ }^{7}$ Ross D. The right and the good. Oxford: Oxford University Press, 2002. P. 30.

${ }^{8}$ Kelsen H., Losano M. La dottrina pura del diritto. Torino : Giulio Einaudi Editore, 1966. P. 32.

${ }^{9}$ D'Agostino F. L'approccio morale al diritto / Scritti in onore di Angelo Falzea. Milano : Giuffrè, 1991. V. I. P. 230.

${ }^{10}$ Kelsen H., Losano M. La dottrina pura del diritto. Torino: Giulio Einaudi Editore, 1966. P. 33. 
Наслідки такої настанови суттєво впливають як на юридичну, так i на політичну систему. Справді, з одного боку, з права викидається його власний етичний зміст, і замість того, щоби вести до пошуку істини для досягнення загального блага, воно зводиться до простого процедурного механізму пошуку згоди. 3 іншого боку, демократична система, яка в ідеалі має бути дієвим «механізмом» захисту прав кожного індивіда на будь-якій стадії і за будь-яких умов його існування, стає «метою», яка служить для збереження інтересів більшості.

По суті, сучасне поняття демократії має характеризуватися не так своїми формальними механізмами, що було властиве моделі демократії минулого століття, як особливою пошаною індивідуальних прав i захистом гідності людської особи ${ }^{11}$. Саме така демократія може називатися правовою державою, у якій сама правляча влада обмежена законами, що спрямовані на захист індивіда, санкціоновані основними принципами конституції, якими не може маніпулювати навіть більшість тих, що є при владі.

Справжня демократія субстанційна ${ }^{12}$, і iї цінність зростає чи зменшується разом із цінностями, які вона втілюе i розвиває. Фундаментальними і невіддільними цінностями в цьому разі є гідність кожної особи, пошана ії невідчужуваних і неприменшуваних прав, а також визнання загального блага як мети і регулюючого критерію політичного життя.

Антропологія пропонує критерії судження про те, що законно санкціоноване силами політичної більшості, і про те, що морально дозволене і служить для блага людини.

Для розвитку суспільства і здорової демократії необхідне нове осмислення людських і моральних цінностей, екзистенціальних i природних, що випливають із самого життя людської істоти та виражають і захищають гідність людської особи, - цінностей, які $з$ огляду на це жоден індивід, жодна більшість і жодна держава не можуть ані створити, ані змінити чи зруйнувати, але повинні лише визнавати, поважати й розвивати.

Вже досить давно в юридичному світі відчувається потреба в поясненні етико-аксіологічного аспекту права i в дослідженні не стільки його джерел, скільки його основ шляхом повернення до тих об'єктивних і універсальних цінностей, які нормативно підтримують його і грунтуються на онтологічній структурі людини як особи ${ }^{13}$.

${ }^{11}$ Blazques N. Bioética fundamental. Madrid: Biblioteca de Autores Cristianos, 1996. P. 46.

12 D'Agostino F. Bioetica e diritto / Medicina e Morale. Roma: UCSC Facoltà di Medicina e Chirurgia A. Gemelli, 1993. № 4. P. 406.

${ }^{13}$ Cotta S. Il diritto nell'esistenza. Linee di ontofenomenologia giuridica. $2^{\text {nd }}$ ed. Milano : Giuffrè, 1991. P. 194. 
Отже, конституції покликані захищати фундаментальні права особи, які необхідні для гарантування упорядкованого спільного проживання громадян і для самої можливості існування їхнього соціального життя. Тому той конституційний мінімум має бути закріплений у конституції кожної держави, бо він $є$ необхідним елементом самого існування будьякого людського суспільства.

Тому від законодавця вимагається не створювати наново, а радше осмислювати потреби людини, що живе в суспільстві, в пошуках не так згоди, як того об'єктивного морального закону, що «вписаний у серце кожної людини і є нормативною точкою відліку самого цивільного закону». Лише на основі таких передумов право може знову віднайти свою істинну функцію, захищену від небезпек етичного релятивізму, який в історії дуже часто служив для виправдання свавілля політичних влад i поєднував справедливість і свободу 3 авторитаризмом i зловживанням, особливо, стосовно найслабших. Тому енцикліка "Evangelium Vitae" («Свангеліє життя») папи Івана Павла II відкрито закликає законодавців поважати «істину права» і звертається до них із закликом сказати мужне «ні» будь-якому насиллю над людським життям і будь-якому свавіллю стосовно нього ${ }^{14}$ [8, № 70].

\section{2. Аборт - порушення основного права людини на життя.}

Права людини і новітні допоміжні репродуктивні технології

Нове бачення сімейних і сексуальних стосунків, новий підхід до становища жінки, до репродуктивної сфери, поширення матеріалістичної культури призвели до узаконення аборту, тобто до вбивства ненародженої дитини. XX ст. було свідком широкомасштабної реформи щодо законів про аборт як максимального чи мінімального дозволу. На сьогодні аборт вилучається з карного права, вважається особистим, суб'єктивним правом жінки, що більше - це «привілейоване» право гарантується та підтримується державою.

Законодавчі новації розпочалися в європейській культурі у 1920 р., коли лібералізовано аборти у Радянському Союзі. За панування комуністичної ідеології та політики після Другої світової війни всі країни Східної Свропи в короткий термін провели реформу з легалізації абортів. Відповідні записи про аборт з'явилися 1956 року в польському, угорському та болгарському законодавствах, 1957 року - у чехословацькому ${ }^{15}$.

${ }^{14}$ Giovanni Paolo II. Lettera Enciclica Evangelium Vitae, 25 marzo 1995. Città del Vaticano : Libreria Editrice Vaticana, 1995. N 70.

15 Терешкевич Г.Т. Основи біоетики та біобезпеки : підручник. Тернопіль : ТДМУ, 2018. С. 97. 
У країнах Західної Європи першою провела реформу Великобританія (Акт про аборт, 1967 р.). У США 22 січня 1973 р. Верховний суд прийняв рішення про лібералізацію абортів в ім'я захисту «права людини на приватне життя». Ця реформа була впроваджена в законодавство Данії (1973), Західної Німеччини (1974), Швеції (1974), Франції (1975), Італії (1978), Люксембургу (1978), Іспанії (1983), Португалії (1984), Голландії (1985), Бельгії (1990). Та йдеться про незавершені законодавчі процеси: закон Німеччини від 27 липня 1992 р. внаслідок постанови Конституційного суду був дуже скоро замінений законом від 21 серпня 1995 р. на користь лібералізації абортів; парламент Польщі в лютому 1993 р. провів реформу старого закону (1956 р.), якою лімітував дозвіл на аборти лише в особливих випадках, спираючись на обов'язок держави опікуватися дитиною від моменту запліднення, у 1996 р. реформа повернулась до старої позиції дозволу внаслідок рішення Конституційного суду Польщі. В Угорщині закон (що стосується проблеми абортів) 1992 р. був замінений більш ліберальним законом від 1 липня 2000 р. внаслідок постанови Конституційного суду у 1998 р. Згідно 3 новою Конституцією Угорщини, яка набула чинності з 1 січня 2012 р., держава зобов'язується захищати людське життя 3 моменту запліднення. Численні рішення верховних судів виявляють таку юридичну тенденцію, яка, не заперечуючи рішення про лібералізацію абортів 22 січня 1973 p. (США), тяжіє до того, щоб надати певну вагу зачатому життю смерті ${ }^{16}$.

Ідеться про законодавчі процеси, які переплітаються 3 позовами до конституційних судів i народними референдумами. Ці процеси народжуються в культурному протистоянні та чергуванні двох течій матеріалізму та персоналізму. Ймовірно, це і $є$ причиною того, що цінність життя нехтувалась спочатку у країнах соціалістичного ладу, де панувала ідеологія матеріалізму, і лише згодом - у країнах Західної Європи, де цей процес був повільним, але й вони були уражені згубною хворобою практицизму у різних його виявах (утилітаризм, гедонізм, лібералізм).

Новітні медичні допоміжні репродуктивні технології, особливо коли вони дають змогу продукувати та довго зберігати плід у пробірці, породили абсолютно безпрецедентну тему становища людського ембріона. Ситуація 3 його правом на життя $\epsilon$ драматичною як щодо факту, так і з погляду права.

Звичайно, становище ембріона в лоні матері відрізняється від становища ембріона у пробірці. Під час вагітності два суб'єкти

${ }^{16}$ Терешкевич Г.Т. Основи біоетики та біобезпеки : підручник. Тернопіль : ТДМУ, 2018. С. 97. 
перебувають між собою в тілесному і дуже особливому зв'язку, який більше ніколи не повторюється. Це ситуація, коли дитина знаходить собі притулок у тілі матері. Вагітність - неповторна умова, коли той, хто перебуває у притулку, (дитина) цілковито довіряється «розуму» і «серцю» того, хто його приймає (матері). I саме ця особлива ситуація «коменсалізму» та «внутріпроживання» або, за влучним формулюванням Конституційного суду Німеччини - «подвійність в одинарності», спричинилась до того, що питання про право на життя ненародженої дитини відійшло на другий план (або залишилось зовсім без уваги) порівняно 3 іншими питаннями (неефективність карних норм; боротьба 3 підпільними абортами для зменшення шкоди здоров'ю жінки через «соціалізацію», тобто за допомогою гарантій соціальної служби, які будуть надаватися безоплатно; ситуація жінки). Кожне з цих питань заслуговує на вивчення, натомість фундаментальне питання про ідентичність і права ембріона може бути «обійдене», тому що ситуація вагітності може виявляти інші аспекти, які відвертають увагу від зачатої та ще ненародженої дитини (ембріона). У випадку репродуктивних технологій ембріон, перебуваючи поза утробою матері, $\epsilon$ «у цілковитому розпорядженні» інших осіб, тобто може використовуватися та піддаватися різноманітним маніпуляціям. Якщо людський живий ембріон зберігається у пробірці, не виникає ситуації аборту, що дає змогу за всієї своєї несправедливості не відповідати на запитання: ким $є$ очікувана дитина, чи має вона право на життя і чи можна іiї безкарно знищити? У світлі нових технологій це питання не може більше відкладатись і потребує термінового вирішення саме через ризик «деперсоніфікації» («перетворення на річ») ембріона.

Протиставлення навмисного аборту та репродуктивної техніки (техніки штучного запліднення) - перший провокує смерть, а друга діє на користь життя - $\epsilon$ поверховим, а отже хибним. Адже ембріони часто продукують не лише для прокреативних цілей, а й для експериментів, досліджень, для «медичних», індустріальних і навіть комерційних цілей, та навіть у випадку, коли метою є допомогти жінці народити дитину, можливе селекціонування (відбір) ембріонів для виявлення 3поміж них таких, які видаються кращими за зовнішніми ознаками чи бажаними характеристиками. Крім того, 3 огляду на недостатню ефективність технологій, у матку переносять декілька ембріонів і продукують їх у великих кількостях для того, щоб залишити «запас» у випадку, якщо імплантація не вдасться з першої спроби. Перенесення в матку декількох ембріонів $\epsilon$ етичною проблемою через велику ймовірність того, що більшість з імплантованих помре, не прижившись в ендометрії (слизовій оболонці матки), та малу надію, що один-єдиний ембріон зможе розвиватись і жити. Можливо, дехто наводитиме 
аргумент, що навіть за природного запліднення частина зародків гине внаслідок мимовільних викиднів - отже, штучне запліднення імітує природне. Та це хибний підхід до питання ${ }^{17}$. Ще більшою $є$ проблема, спричинена продукуванням i замороженням великої кількості ембріонів.

На цьому етапі розвитку технологій їхня слабка ефективність, інвазивний характер відбору в жіночому тілі овоцитів, складність замороження яйцеклітини та відносна легкість замороження ембріона наштовхнули «дослідників» на думку висунути фармакологічне припущення про гіперовуляцію, яка уможливить одночасний відбір багатьох яйцеклітин і продукування численних ембріонів на запас. Уже сам процес замороження, а згодом розмороження спричиняє смерть певної кількості зародків. Однак найдраматичніший аспект стосується невикористаних заморожених ембріонів: знищувати їх після закінчення юридичного строку дії, як чинять із продуктами харчування або фармацевтичними засобами після закінчення терміну їхньої придатності, чи використовувати як матеріал для експериментів?

Відтак $є$ простір для маніпуляцій із ембріоном i, як наслідок, можливість виконувати замовлення на фізичні та генетичні характеристики. Просуваючись далі, можна припустити, що вагітність жінки буде замінена вагітністю тварини чи механічною вагітністю; або що через схрещення між людиною і твариною можна буде отримати новий тип істоти. Тому вирішення питання природи, гідності та прав людського ембріона абсолютно неминуче й невідкладне.

\section{3. Право на життя в контексті прав людини}

У європейських конституціях, особливо в повоєнних, $є$ твердження, що людська гідність і права людини мають вирішальне значення i становлять мету державної організації. У деяких конституціях (німецькій, португальській, польській) виразно наголошено на праві на життя. I тому треба обов'язково зрозуміти, чи право на життя ембріона входить до таких прав. Це і $є$ вирішальним пунктом під час мотивації деяких конституційних постанов. Що конституції вважають правами людини i, особливо, як вони їх інтерпретують? Це важливі дані, бо цілком зрозуміло, що конституційне право певної країни, в якому стверджується існування прав зачатої дитини іменем прав людини, проголошених Універсальною декларацією, потребує універсальної інтерпретації, що відіграє роль у судових розглядах інших конституційних судів, тому що такі універсальні права розглядаються також в інших декретах. Якщо поміркуємо про все сказане і написане 3

${ }^{17}$ Sgreccia E. Manuale di bioetica. Milano: Vita e Pensiero, 1999. V. I. P. 541. 
приводу прав людини - i в поодиноких указах, i на міжнародних конференціях - то зрозуміємо, як важливо поглибити роздуми щодо того, якою $є$ інтерпретація конституційної юрисдикції права на життя в контексті прав людини.

Тепер доцільно звернути увагу на двозначність теорії прав людини, двозначність, яка є ще більшою у протиставленні 3 правом на життя зародка. 3 одного боку, вся теорія прав людини може бути зведена нанівець, якщо не визначено власника таких прав і концепції людської істоти («члена людської сім’ї», як записано у преамбулі до Загальної декларації прав людини, 1948 р.) смерті ${ }^{18}$, або якщо питання про визначення критеріїв буде залишене на розсуд практичного законодавства. 3 іншого боку, залишається невизначеним питання фактичної чинності прав людини. Тобто потрібно з'ясувати, чи вони (права людини) юридично визначають зобов'язуючі дії такою мірою, якою вони включені у міжнародні трактати, конституційні хартії, внутрішні нормативи, чи вони зобов'язуються незалежно від таких посилань. У першому випадку різні переліки прав і Декларація прав людини 1948 р. є лише закликами до суду присяжних. Із цим питанням пов'язане також питання, що стосується ембріона. Та якщо права людини є юридичною інстанцією препозитивною, юридично чинною, тобто незалежно від їхнього письмового викладу, тоді їх неможливо інтерпретувати за звичайними герменевтичними критеріями, властивими позитивному (практичному) праву. Тоді неважливо знати, чи той, хто написав Декларацію 1948 р. або Європейську конвенцію про захист прав людини $\mathrm{i}$ основних свобод $1950 \mathrm{p}$ смерті ${ }^{19}$, стверджуючи право на життя кожної людини, чи кожного громадянина, чи кожної особи мав на увазі ембріон людини. Так звані критерії технологічної та історичної інтерпретації стосуються лише позитивного права. Наміри законодавця або комісій із підготовки закону мають значення лише для інтерпретації їх у письмово викладеному законі, а не для норми, яка не написана на папері, але існує у природі або походить від людської гідності та моралі. Якщо права людини передують певному закону, то нас мало цікавить думка законодавця, оскільки права людини судять також самого законодавця.

18 Загальна декларація прав людини: прийнята і проголошена резолюцією 217 А (III) Генеральної Асамблеї ООН від 10 грудня 1948 р. База даних «Законодавство України». URL: http://zakon.rada.gov.ua/laws/show/995_015.

19 Загальна декларація прав людини: прийнята і проголошена резолюцією 217 А (III) Генеральної Асамблеї ООН від 10 грудня 1948 р. База даних «Законодавство України». URL: http://zakon.rada.gov.ua/laws/show/995_015.

Європейська конвенція про захист прав людини та основоположних свобод. Рим, 4.XI.1950. URL: www.hri.org/docs/ECHR50.html. 
Це складне питання, але обов'язкове, якщо ми не хочемо ще раз звести нанівець теорію прав людини. А людський ембріон перебуває всередині цієї проблеми, має вирішальну функцію, яка проливає світло на кожну з цих двозначностей. Тому проблему відносин між правом на життя зародка і правами людини треба оцінювати в комплексі 3 культурою, історією та практикою.

Тема прав людини стає щораз важливішою після проголошення Загальної декларації прав людини від 10 грудня 1948 р., яка має дуже сильне символічне навантаження. Коментатори зауважують, що ця Декларація відрізняється від будь-яких попередніх актів, наближених до неї, починаючи з Великої Хартії Вольностей (1215 р., Англія) ${ }^{20}$ аж до Декларації прав людини і громадянина (1792р., Франція $)^{21}$. Крім універсального аспекту, Декларація 1948 р. визначає межі влади, претендує бути остаточним Проєктом миру, свободи та справедливості.

Мета Декларації 1948 р., як роз'яснено у преамбулі, - це «визнання гідності кожного члена людської сім'ї» та його «однакових i невіддільних прав». Символічну насиченість Декларації можна вловити, беручи до уваги час її створення. Це саме «серце» XX століття 3 його трагедіями та надіями. У першій половині століття були найбільші прояви насильства, і в 1948 р. ще залишалася скорботна пам'ять про них. Крім того, початок другої половини століття характеризувався страхом перед майбутніми можливими трагедіями, які можуть призвести до кінця світу. Тероризм, гонка ядерних озброєнь; мир, що тримається на страху (політика стримування та репресій), - характерні ознаки цього періоду. I саме в цей час представники всіх народів гарантують, як це зазначено в преамбулі Декларації, надію на мир, справедливість та свободу як «інтелектуальний вчинок»: визнання гідності кожної людської істоти.

Те, що це зобов'язує розглянути юридичний статус людського ембріона, очевидно. За Декларацією 1948 р. з'явилися інші, які намагались закріпити гарантію фундаментальних прав, що стосуються як окремих категорій суб'єктів або питань, так і специфічних територіальних площин ${ }^{22}$.

Останнім часом були намагання ввести питання про статус ембріона як людської особи в хартії та конвенції з прав людини, зокрема в

20 Magna Charta Libertatum / Runnymede (GB) 15 giugno 1215. URL: http://www.studiperlapace.it/documentazione/magnacharta.html.

${ }^{21}$ Déclaration des Droits de l'Homme et du Citoyen/Décret des 21-22 septembre 1792 / Constitution du 24 juin 1793. URL: https://www.conseil-constitutionnel.fr/les-constitutionsdans-1-histoire/constitution-du-24-juin-1793.

${ }^{22}$ Casini M. Il diritto alla vita del concepito nella giurisprudenza europea le decisioni della Corti Costituzionali e degli organi sovranazionali di giustizia. Padova : CEDAM, 2001. P. 15. 
Конвенцію Ради Європи з прав людини та біомедицині (04.04.1997р.) ${ }^{23}$, у Протокол 3 клонування людини ${ }^{24}$, у Резолюцію Європейського Парламенту ${ }^{25}$, у Рекомендації Європейської Ради ${ }^{26}$, Універсальну декларацію ЮНЕСКО про людський геном та права людини (1997р.) $)^{27}$, Директиву 98/44 Європейського Парламенту та Ради Європейського Союзу про юридичний захист біотехнологічних винаходів (1998р.) ${ }^{28}$.

Можна сказати, що біоправо постає не тільки як галузь внутрішнього законодавства, яке визначається на основі практичних, дидактичних або систематичних критеріїв, а також як важлива частина прав людини, що більше - як вирішальна частина, як аспект теорії про людську гідність, оскільки тоді, коли людський ембріон у випадку кризи гуманності не посідає нічого, крім себе самого, біоправо ставить радикально питання про зміст людської гідності. Біоправо з'являється, як вхідні двері до конкретного розвитку доктрини людських прав. Було б доволі цікаво порівняти всі міжнародні документи з прав людини та конституції всього світу, там де вони існують (в Африці та Азії, в

${ }^{23}$ Конвенція про захист прав та гідності людини у зв'язку з використанням досягнень біології та медицини (Конвенція про права людини та біомедицину), (ETS-164), № 994_334, від 4 квітня 1997 р., Ов’єдо (Австрія). URL: https:// zakon.rada.gov.ua/ laws/show/994_334.

24 Додатковий протокол про заборону клонування людини до Конвенції Ради Європи «Про права людини та біомедицину» № 994_526 від 12 січня 1998 р. URL: https://zakon.rada.gov.ua/laws/show/994_526.

${ }^{25}$ Risoluzioni del parlamento europeo del 16 marzo 1989 sui problemi etici e giuridici della manipolazione genetica e sulla fecondazione artificiale in vivo e in vitro / Medicina e Morale. Rivista internazionale di Bioetica. Centro di Bioetica dell'Università Cattolica del Sacro Cuore, Facoltà di Medicina e Chirurgia A. Gemelli, Roma. № 3. 1989. P. 579-587: 587-590;

Risoluzione del Parlamento europeo sulla clonazione umana del 12.3.1997/ Medicina e Morale. Rivista internazionale di Bioetica. Centro di Bioetica dell'Università Cattolica del Sacro Cuore, Facoltà di Medicina e Chirurgia A. Gemelli, Roma. № 2 1997. P. 325-327.

${ }^{26}$ Raccomandazione n. 934 del 26. 01.1982 sull' ingegneria genetica / Casini C. (a cura di) Il Parlamento Europeo per uno statuto giuridico dell'embrione umano. Roma : Ed. Cinque Lune. 1989. P. 148-153;

Raccomandazione n.1046 del 24.09.1986 sull' utilizzazione di embrioni e feti umani a fini diagnostici, terapeutici, scientifici, industriali e commerciali / Casini C. (a cura di) Il Parlamento Europeo per uno statuto giuridico dell'embrione umano. Roma : Ed. Cinque Lune, 1989. P. 155-163;

Raccomandazione n. 1100 del 02.02.1989 sulla ricerca scientifica relativamente agli embrioni e feti umani / Casini C. (a cura di) Il Parlamento Europeo per uno statuto giuridico dell'embrione umano. Roma : Ed. Cinque Lune. 1989. P. 165-176.

27 Загальна декларація про геном людини і права людини від 11 листопада 1997 p. URL: http://unesco.org.ua/ua/archive/documents/downloads/genome.pdf.

${ }^{28}$ Directive of the European Parliament and of the Council of the European Union 98/44/ EC of 6 July 1998 on the legal protection of biotechnological inventions. Official Journal. 1998. L 213. P. 13-21. 
Америці, на Півдні та Півночі), тоді можна було б простежити тенденції, залежні від різних культур і традицій.

Немає універсальної збірки конституцій, а завдання зібрати їх та зробити доступними щодо мови досить складне. Тому обмежимо наше дослідження територією Європи. Європейські конституції доступні не тільки територіально. Ідея європейської єдності, що знайшла своє вираження в Свропейському Союзі, пов'язана 3 проєктом миру та возвеличення гідності й прав людини. Отже, конституції європейських держав мають особливе значення, щоб простежити, як впливає право на життя ембріона на основну концепцію юстиції. Після зруйнування Берлінської стіни Рада Свропи налічує 40 європейських держав, а Європейський Союз - досить важливий політично - має тенденцію дедалі більше розширюватись, і перспектива утворення єдиної Європи «від Атлантики до Уралу» не $\epsilon$ нереальною. Слушно зауважити, що Свропейський Союз пройшов довгий економічний шлях, який нині вимагає більшої гармонізації та політичної уніфікації. Щоб Європейський Союз не став просто суспільним ринком, він потребує визначення, яку ідею Європи хочемо реалізувати? 3 цих мотивів права ембріона також набувають у проєкті Свропейської Конституції значення вирішального елемента. Варто зауважити, що Україна, яка $\epsilon$ європейською державою і постійно декларує свій європейський вибір, стосовно прав ембріона не має чітко визначеного законодавства. Проблемою для нашої країни $є$ велика кількість абортів, торгівля дітьми чи ембріонами, до яких причетні їі громадяни. Державні й законодавчі органи повинні негайно вживати заходів щодо захисту прав ембріона в контексті європейського законодавства та етичних вимог сьогодення.

Аналіз рішень конституційних судів в окремих країнах, а також аналіз рішень судових органів Ради Європи та Європейського Союзу дають змогу ствердити, що в юриспруденції країн $€$ посилання на деякі 3 цих рішень, зокрема на Європейську конвенцію із захисту прав людини та фундаментальних свобод, що певним чином створюють базу загальноєвропейського конституційного права. Дебати щодо права на життя тривають не лише у вузьких колах, а також у сферах політики, культури, масмедіа, у повсякденному житті людей.

Рекомендація Парламентської асамблеї Ради Європи № 1046/1986 проголошує, що зародкам та ембріонам людини також властива людська гідність, тому за всіх умов слід ставитися до них із належною повагою і будь-яке втручання в їхній організм, навіть якщо вони нежиттєздатні, повинно бути заборонене (експерименти, взяття органів 
для трансплантації тощо) (п. 10) ${ }^{29}$. Забезпечити це мають законодавчі органи кожної країни.

Логічним доповненням до Європейської конвенції прав людини $(1950 \text { р.) })^{30}$ та Європейської соціальної хартії (1961 р., попр. 1996 р.) $)^{31} \epsilon$ Європейська конвенція «Про захист прав та гідності людини у зв'язку з використанням досягнень біології і медицини» (1997 р. $)^{32}$, яку підписала Україна разом із 35 державами, 3 них 28 держав іiі ратифікували, але Україна не ратифікувала цю конвенцію. Це означає, що законодавчі акти стосовно охорони життя і здоров'я повинні формуватися згідно 3 вимогами останньої Конвенції, заснованої на засадах біоетики.

Загальна декларація про біоетику та права людини, прийнята ЮНЕСКО (2005 р.) $)^{33}$ офіційно на рівні цієї міжнародної організації визнала біоетику як глобальну галузь знань, що потребує правового забезпечення і пріоритетної уваги від законодавців усіх країн світу. Загальна декларація про біоетику та права людини, фактично, стала першим універсальним джерелом міжнародного біоетичного права, в якому викладено основоположні принципи біоетики і яка підкреслила міжнародний глобальний характер біоетичних проблем.

Законодавство України в галузі охорони здоров'я згідно зі ст. 9 Основного Закону України адаптується до відповідних міжнародних документів, якщо є згода на це Верховної Ради ${ }^{34}$. Через законодавство України імплементуються основні документи міжнародних організацій щодо дотримання норм і засад біоетики у практиці охорони здоров'я, основою яких мало б бути законодавчо закріплене право людини на гідне життя й пошану людської особистості.

Право людини на гідне життя й пошану людської особистості яскраво викладено в концепціях відомих філософів, учених i гуманістів-практиків - ученні про біосферу та ноосферу В. Вернадського (1863-1945, християнському еволюціонізмі Т. де

${ }^{29}$ Raccomandazione n.1046 del 24.09.1986 sull' utilizzazione di embrioni e feti umani a fini diagnostici, terapeutici, scientifici, industriali e commerciali / Casini C. (a cura di) Il Parlamento Europeo per uno statuto giuridico dell'embrione umano. Roma: Ed. Cinque Lune. 1989. pp. 155-163

${ }^{30}$ Свропейська конвенція про захист прав людини та основоположних свобод. Рим, 4.XI.1950. URL: www.hri.org/docs/ECHR50.html. (Дата звернення 03.01.2020).

${ }_{31}$ Свропейська соціальна хартія, 1961 р., переглянута Радою Свропи. Страсбург, 3 травня 1996 p. URL: www.coe.int/T/E/Human_Rights/Esc/ (Дата звернення 03.01.2020).

${ }^{32}$ Конвенція про захист прав та гідності людини щодо застосування біології та медицини 1997 p. P€. URL: conventions.coe.int/Treaty/EN/Treaties/Html/164.htm

33 Загальна декларація про біоетику та права людини, прийнята ЮНЕСКО, 19 жовтня 2005 p. URL: http://unesdoc.unesco.org/images/0014/001461/146180r.pdf.

34 Конституція України: прийнята на п’ятій сесії Верховної Ради України 28 червня 1996 р. Київ : Велес, 2005. 48 с. (Серія видань «Офіційний документ»). 
Шардена (1881-1955, етиці «благоговіння перед життям» А. Швейцера (1875-1965).

Належність до людського роду - це визнання права на гідність кожного, і цього досить, бо решта атрибутів (краса, успіх, здоров'я, багатство, розум, дорослість і та. ін.) прирівнюється до другорядних i таких, що нездатні характеризувати гідність, яка вже цілковито міститься в цій належності. I роздуми про право на життя плода вкладаються в цей контекст, тому що «першим виявом людської гідності є право на життя, - це інтелектуальний жест, який повертає їй правду та позбавляє двозначності» ${ }^{35}$.

Історичний рух, який досі визнавав людську гідність і людські права, може бути графічно зображений горизонтальною лінією, що проходить через усі вищі рівні цивілізованості. Епоха, в якій живемо, вимагає терміново довести до завершення цей процес також по вертикальній лінії, що полягає в рівній гідності, у визнанні фундаментальних прав людини та у праві на життя кожної людської істоти від моменту запліднення до Богом призначеного відходу (природної смерті).

\section{ВИСНОВКИ}

Науковими дослідженнями природи людського ембріона доведено, що від моменту запліднення він $є$ унікальною людською істотою, має в собі всі характеристики людської особистості та керовану особистим геномом свою власну проєкт-програму життя.

Дуже важливо, щоб людську природу особи в ії ембріональному стані усвідомлювали всі люди. Особливо це стосується тих, хто приймає законодавчі акти стосовно узаконення чи заборони аборту, який $є$ не лише етичним злочином, але й прямим порушенням основних прав людини, кримінальним злочином проти людського життя, функція оборони і захисту якого покладена на державу.

Засада неприпустимості дискримінації в ім'я рівної гідності всіх людських істот має стосуватися всіх періодів людського існування - від моменту запліднення до природної смерті, охоплюючи особливі етапи (фази): початковий, страждання та вмирання.

Якщо вишкіл публічних управлінців відбуватиметься на моральноетичному грунті біоетики, тоді вони будуть задіяними у протидії культурі смерті, натомість пропагуючи цивілізацію життя.

$\mathcal{E}$ вкрай важливо, щоб задіяні публічному управлінні кадри стояли на позиціях біоетики і відповідно свої дії будували на цих засадах.

${ }^{35}$ Sgreccia E. Manuale di bioetica. Milano : Vita e Pensiero, 1999. V. I. P. 349-350. 
Необхідно визнати за ембріоном право на життя та внести корективи в українське законодавство на його користь.

Органам державної влади України слід виконати вимогу «Конвенції про захист прав людини та основ свобод», гарантуючи право на життя кожній зачатій та ще ненародженій людині;

Для збереження здоров'я нашого суспільства, підняття його духовного та морально-етичного рівня необхідно перенести у площину публічного управління засади біоетики як необхідну передумову розвитку цивілізованої Держави Україна.

\section{АНОТАЦІЯ}

Демократичні зміни, що відбуваються в країнах пострадянського простору, зокрема в Україні, створюють унікальну можливість для аналізу й оцінки позитивних сторін біоетики країн Західної Європи, їх творчого розвитку й використання на практиці.

$\mathcal{E}$ вкрай важливо, щоб задіяні в публічному управлінні кадри стояли на позиціях біоетики i, відповідно, свої дії будували на ії засадах. Для збереження здоров'я суспільства та підняття його духовного та морально-етичного рівня необхідно перенести у площину публічного управління, зокрема, в систему охорони здоров'я вимоги біоетики як необхідну передумову розвитку цивілізованої держави Україна.

Життя людини бере початок не в момент народження, як записано у наших паспортах, а у момент злиття батьківських гамет. Саме в цю мить відбувається диво сотворення людини, 3 тільки їй властивим набором генів та, відповідно, особистісних якостей, 3 неповторними характеристиками та талантами. За 38-40 тижнів внутрішньоутробного розвитку ця людська істота стане здатною до існування поза межами материнського лона й отримає ім'я. Але, на жаль, така доля чекає далеко не всіх зачатих людських істот через поширену у світі практику абортів, контрацепцію, штучне запліднення та інші сумнівні «здобутки» сучасної медицини, нехтуючи правами маленької людської істоти, пропагуючи в суспільстві «культуру смерті», що є замахом на божественну гідність людської особи.

Пропоноване дослідження ставить перед органами державної влади, місцевого самоврядування та громадськими організаціями завдання визнати за ембріоном основне право на життя та ввести корективи в українське законодавство на його користь.

\section{ЛIТЕРАТУРА}

1. Comitato Nazionale per la Bioetica. Identitá e statuto dell'embrione umano / Pressidenta del Consiglio dei Ministri. Dipartimento per l'Informazione e l'Editora. Roma, 22 giugno 1996. 51 p. 
2. Загальна декларація прав людини: прийнята i проголошена резолюцією 217 А (ІІІ) Генеральної Асамблеї ООН від 10 грудня 1948 p. База даних «Законодавство Украӥни». URL: http://zakon.rada.gov.ua/ laws/show/995_015 (дата звернення: 06.05.2020).

3. Giovanni Paolo II. Lettera Enciclica Evangelium Vitae, 25 marzo 1995. Città del Vaticano : Libreria Editrice Vaticana, 1995. 192 p.

4. Терешкевич Г.Т. Основи біоетики та біобезпеки : підручник. Тернопіль : ТДМУ, 2018. 400 с.

5. Соціально-філософські та етичні проблеми медицини : навч. посіб. / за заг. ред. А.П. Алексєєнко, В.М. Лісового. Харків : Колегіум, 2010. $340 \mathrm{c}$.

6. Giovanni Paolo II. Lettera Enciclica Evangelium Vitae, 25 marzo 1995. Città del Vaticano : Libreria Editrice Vaticana, 1995. 192 p.

7. Ross D. The right and the good. Oxford : Oxford University Press, 2002. $183 \mathrm{p}$.

8. Kelsen H., Losano M. La dottrina pura del diritto. Torino : Giulio Einaudi Editore, 1966. 420 p.

9. D'Agostino F. L'approccio morale al diritto / Scritti in onore di Angelo Falzea. Milano : Giuffrè, 1991. V. I. P. 219-242.

10. Kelsen H., Losano M. La dottrina pura del diritto. Torino : Giulio Einaudi Editore, 1966. 420 p.

11. Blazques N. Bioética fundamental. Madrid : Biblioteca de Autores Cristianos, 1996. 646 p.

12. D'Agostino F. Bioetica e diritto / Medicina e Morale. Roma : UCSC Facoltà di Medicina e Chirurgia A. Gemelli, 1993. № 4. P. 675-691.

13. Cotta S. Il diritto nell'esistenza. Linee di ontofenomenologia giuridica. $2^{\text {nd }}$ ed. Milano : Giuffrè, 1991. $312 \mathrm{p}$.

14. Giovanni Paolo II. Lettera Enciclica Evangelium Vitae, 25 marzo 1995. Città del Vaticano : Libreria Editrice Vaticana, 1995. 192 p.

15. Терешкевич Г.Т. Основи біоетики та біобезпеки : підручник. Тернопіль : ТДМУ, 2018. 400 с.

16. Терешкевич Г.Т. Основи біоетики та біобезпеки : підручник. Тернопіль : ТДМУ, 2018. 400 с.

17. Sgreccia E. Manuale di bioetica. Milano: Vita e Pensiero, 1999. V. I. 817 p.

18. Загальна декларація прав людини: прийнята i проголошена резолюцією 217 А (ІІІ) Генеральної Асамблеї ООН від 10 грудня 1948 p. База даних «Законодавство України». URL: http://zakon.rada.gov.ua/ laws/show/995_015 (дата звернення: 06.05.2020).

19. Загальна декларація прав людини: прийнята i проголошена резолюцією 217 А (ІІІ) Генеральної Асамблеї ООН від 10 грудня 1948 р. 
База даних «Законодавство України». URL: http://zakon.rada.gov.ua/ laws/show/995_015; (дата звернення: 06.05.2020);

Свропейська конвенція про захист прав людини та основоположних свобод. Рим, 4.XI.1950. URL: www.hri.org/docs/ECHR50.html. (дата звернення: 06.05.2020).

20. Magna Charta Libertatum /Runnymede (GB) 15 giugno 1215. URL: http://www.studiperlapace.it/documentazione/magnacharta.html (дата звернення: 06.05.2020).

21. Déclaration des Droits de l'Homme et du Citoyen/Décret des 21-22 septembre 1792. Constitution du 24 juin 1793. URL: https://www.conseil-constitutionnel.fr/les-constitutions-dans-l-histoire/ constitution-du-24-juin-1793 (дата звернення: 06.05.2020).

22. Casini M. Il diritto alla vita del concepito nella giurisprudenza europea le decisioni della Corti Costituzionali e degli organi sovranazionali di giustizia. Padova : CEDAM, 2001. 386 p.

23. Конвенція про захист прав та гідності людини у зв'язку 3 використанням досягнень біології та медицини (Конвенція про права людини та біомедицину), (ETS-164), № 994_334, від 04.04.1997 p., Ов'єдо (Австрія). URL: https://zakon.rada.gov.ua/laws/show/994_334 (дата звернення: 06.05.2020).

24. Додатковий протокол про заборону клонування людини до Конвенції Ради Європи «Про права людини та біомедицину» № 994_526 від 12 січня 1998 p. URL: https://zakon.rada.gov.ua/laws/ show/994_526 (дата звернення: 06.05.2020).

25. Risoluzioni del parlamento europeo del 16 marzo 1989 sui problemi eticie giuridici della manipolazione genetica e sulla fecondazione artificiale in vivo e in vitro / Medicina e Morale. Rivista internazionale di Bioetica. Centro di Bioetica dell'Università Cattolica del Sacro Cuore, Facoltà di Medicina e Chirurgia A. Gemelli, Roma. № 3. 1989. P. 579-587: 587-590;

Risoluzione del Parlamento europeo sulla clonazione umana del 12.3.1997/Medicina e Morale. Rivista internazionale di Bioetica. Centro di Bioetica dell'Università Cattolica del Sacro Cuore, Facoltà di Medicina e Chirurgia A. Gemelli, Roma. № 2 1997. P. 325-327.

26. Raccomandazione n. 934 del 26. 01.1982 sull' ingegneria genetica / Casini C. (a cura di) Il Parlamento Europeo per uno statuto giuridico dell'embrione umano. Roma : Ed. Cinque Lune. 1989. P. 148-153;

Raccomandazione n.1046 del 24.09.1986 sull' utilizzazione di embrioni e feti umani a fini diagnostici, terapeutici, scientifici, industriali e commerciali / Casini C. (a cura di) Il Parlamento Europeo per uno statuto giuridico dell'embrione umano. Roma : Ed. Cinque Lune. 1989. P. 155-163;

Raccomandazione n. 1100 del 02.02.1989 sulla ricerca scientifica relativamente agli embrioni e feti umani / Casini C. (a cura di) Il Parlamento 
Europeo per uno statuto giuridico dell'embrione umano. Roma : Ed. Cinque Lune. 1989. P. 165-176.

27. Загальна декларація про геном людини і права людини від 11 листопада 1997 p. URL: http://unesco.org.ua/ua/archive/documents/ downloads/genome.pdf. (дата звернення: 06.05.2020).

28. Directive of the European Parliament and of the Council of the European Union 98/44/ EC of 6 July 1998 on the legal protection of biotechnological inventions. Official Journal. 1998. L 213. P. 13-21.

29. Конституція України : прийнята на п'ятій сесії Верховної Ради України 28 червня 1996 р. Київ : Велес, 2005. 48 с. (Серія видань «Офіційний документ»).

30. Raccomandazione n.1046 del 24.09.1986 sull utilizzazione di embrioni e feti umani a fini diagnostici, terapeutici, scientifici, industriali e commerciali / Casini C. (a cura di) Il Parlamento Europeo per uno statuto giuridico dell'embrione umano. Roma : Ed. Cinque Lune. 1989. P. 155-163.

31. Свропейська конвенція про захист прав людини та основоположних свобод. Рим, 4.XI.1950. URL: www.hri.org/docs/ ECHR50.html (дата звернення: 06.05.2020).

32. Свропейська соціальна хартія, 1961 р., переглянута Радою Свропи. Страсбург, 3 травня 1996 p. URL: http://www.coe.int/T/E/ Human_Rights/Esc/_(дата звернення: 06.05.2020).

33. Конвенція про захист прав та гідності людини щодо застосування біології та медицини 1997 p. PC. URL: http://conventions.coe.int/ Treaty/EN/Treaties/Html/164.htm (дата звернення: 06.05.2020).

34.Загальна декларація про біоетику та права людини, прийнята ЮНЕСКО, 19 жовтня 2005 p. URL: http://unesdoc.unesco.org/images/ 0014/001461/146180r.pdf._(дата звернення: 06.05.2020).

35. Sgreccia E. Manuale di bioetica. Milano : Vita e Pensiero, 1999. V. I. $817 \mathrm{p}$.

\section{Information about author: Tereshkevych H. T. (sister Diohena), Ph.D. in Public Administration,} Associate Professor of the Department of Philosophy and Economy of Danylo Halytsky Lviv National Medical University, 69, Pekarska str., L'viv city, 79010, Ukraine Doctorate in the Department of Parliamentarism and Political Management of the National Academy for Public Administration under the President of Ukraine 12/2, Akademika Romodanova str., Kyiv, 04050, Ukraine 